\title{
A new species of Megaselia Rondani (Diptera: Phoridae) and two newly found species from Poland
}

\author{
R. Henry L. DiSNEY*and Ewa DURSKA** \\ *Department of Zoology, University of Cambridge, Cambridge CB2 3EJ, England; e-mail: rhld2@hermes.cam.ac.uk, \\ ** Museum and Institute of Zoology, Polish Academy of Sciences, Wilcza 64, 00-679, Warsaw, Poland; \\ e-mail:edurska@miz.waw.pl
}

\begin{abstract}
The new species to science - Megaselia garwolinensis is described from the post-fire area in the Garwolin Forest $\mathrm{n}$. Warsaw. The other two species found during the study: Megaselia bifida and $M$. citronella are for the first time recorded in Poland.
\end{abstract}

Key words: scuttle flies, Megaselia, Poland, Garwolin Forest, new species

\section{INTRODUCTION}

The Phoridae is the most taxonomically and ecologically diverse families of Diptera, of small (ca. 2-3 mm body length), hump-backed flies, with a scuttle way of moving. Winged individuals are easily recognized under microscope, by their distinctive wing venation (Disney 1994). "Secretive habits and living of dark, damp and moldy areas are common throughout the Phoridae" (Oldroyd 1964).

The number of Phoridae species of the Polish fauna amounted until now 345 . Of about $70 \%$ of the scuttle fly species belongs to the cosmopolitan genus Megaselia (Disney 2001a; Disney \& Durska 1998, 2011).

Among a collection of the scuttle flies from the Garwolin Forest near Warsaw, Central Poland were three species that are the first records for Poland; Megaselia bifida Disney, $M$. citrinella Buck and a new species that is described below.

\section{MATERIAL AND METHODS}

The scuttle fly specimens were collected in the post-fire area of the Garwolin Forest $\left(51^{\circ} 58^{\prime} 7^{\prime \prime} \mathrm{N}, 21^{\circ} 39^{\prime} 40^{\prime \prime} \mathrm{E}\right)$ in Central-East Poland. On the 6th of July, 2010 an anthropogenic fire destroyed ca. 1.5 ha of the Garwolin Forests. The tree stands are composed mainly of Scots pine (Pinus sylvestris), with a lower proportion of Norway spruce (Picea abies), oaks (Quercus spp.), birches (Betula spp.) and occasional other species. The sampling was conducted in the second and third year after the disturbance mentioned above. The small open-area habitat after weak fire understorey was left for natural regeneration.

Among the collection of scuttle flies (Diptera, Phoridae) from the Garwolin Forest, in July 2012 were three species that are the first records for Poland; Megaselia bifida Disney, $M$. citrinella Buck and a new species that is described below.

The specimens were preserved in $70 \%$ ethanol. Representative specimens from the samples were mounted on slides in Berlese Fluid (Disney 2001b) and examined under a compound microscope and deposited in the Museum and Institute of Zoology, Polish Academy of Sciences (MIZ PAS) and the University of Cambridge Museum of Zoology (UCMZ). 


\section{RESULTS \\ Megaselia garwolinensis Disney, n. sp. \\ (Figs 1-7)}

Diagnosis. In the key to species recorded from the British Isles (Disney 1989) this species runs to couplet 191. Both options are ruled out as $M$. errata (Wood) has more than 10 hairs on each cercus and more than 5 axillary bristles on the wing, and $M$. brunneipennis Costa has a much shorter anal tube and the lower faces of its labella have numerous spinules.

Male only. Head as in Fig. 1, but between the anterior ocellus and the upper supra-antennal bristles the dense but very fine microtrichia are restricted to the edges (adjacent to the eyes) and a strip either side of the median furrow. Cheek with four bristles and jowl with two that are longer. The subglobose postpedicels light brown (Fig. 1), with a few subcutaneous pit sensilla (SPS) vesicles, the largest almost as large as the socket of a lower supra-antennal bristle. Palps and proboscis as in Fig. 1; the labella with only a few short spinules below. Thorax brown. Three notopleural bristles and no cleft in front of these. Mesopleuron bare. Scutellum with an anterior pair of small hairs and a posterior pair of bristles. Abdominal tergites brown with moderate hairs, which are longest at rear of T6 (Fig. 2). Venter light gray (Fig. 2), and with hairs on segments 3-6. Hypopygium as in Figs 2-4, there being two subequal hypandrial lobes (Fig. 4). Apart from brown patch on mid coxa and tip of hind femur legs yellow. Fore tarsus with posterodorsal hair palisade on segments 1-4 (Fig. 5). Mid tibia as in Fig. 6. Hairs below basal half of hind femur longer than those of anteroventral row of outer half (Fig. 7). Hind tibia with 14 differentiated posterodorsal hairs and spinules of apical combs simple. Wings 1.7-1.8 $\mathrm{mm}$ long. Costal index 0.48 . Costal ratios $3.2: 3.5: 1$. Costal cilia (of section 3) $0.06 \mathrm{~mm}$ long; hair at base of vein 3 minute; two unequal axillary bristles, the outer being $0.10-0.11 \mathrm{~mm}$ long. Sc just reaching R1. Costa pale but rest of thick veins light brown, thin veins brown, 7 being paler than the rest. Membrane tinged brownish gray (evident to naked eye when viewed against a white background). Haltere knob pale dusky yellow.

Material. Holotype male, Poland, Garwolin, 17 Jul-2 Aug 2012, (MIZ PAS, 28-54). Paratype male, as holotype (UCMZ, 28-53).

Etymology. Named after the type locality.

\section{Megaselia bifida Disney, 1983}

Megaselia bifida Disney, 1983: 228.

Material. 2 males, Poland, Garwolin, 17 Jul-2 Aug 2012.

Distribution: This species has previously been reported from the British Isles, Italy and Sweden.

\section{Megaselia citrinella Buck, 2001}

Megaselia citrinella Buck, in Buck \& Disney, 2001: 88.

Material. 2 males. Poland, Garwolin, 17 Jul-2 Aug 2012.

This species has previously been reported from Germany, England, Spain, Sweden, The Netherlands and the Nearctic Region.

\section{COMMENTS}

Megaselia is one of the largest, most biologically diverse and taxonomically difficult genera in the entire animal kingdom' (Marshall 2012). About 1500 species are known, but with 
it being estimated that there are at least 10,000 species it is evident that the majority remain to be described. In view of this situation a brief diagnosis is less useful than an indication as to how a new species runs down in existing relevant keys, with an indication as to how it differs from the species arrived at; along with how it differs from species added since the key and that will run down to the same couplet(s).

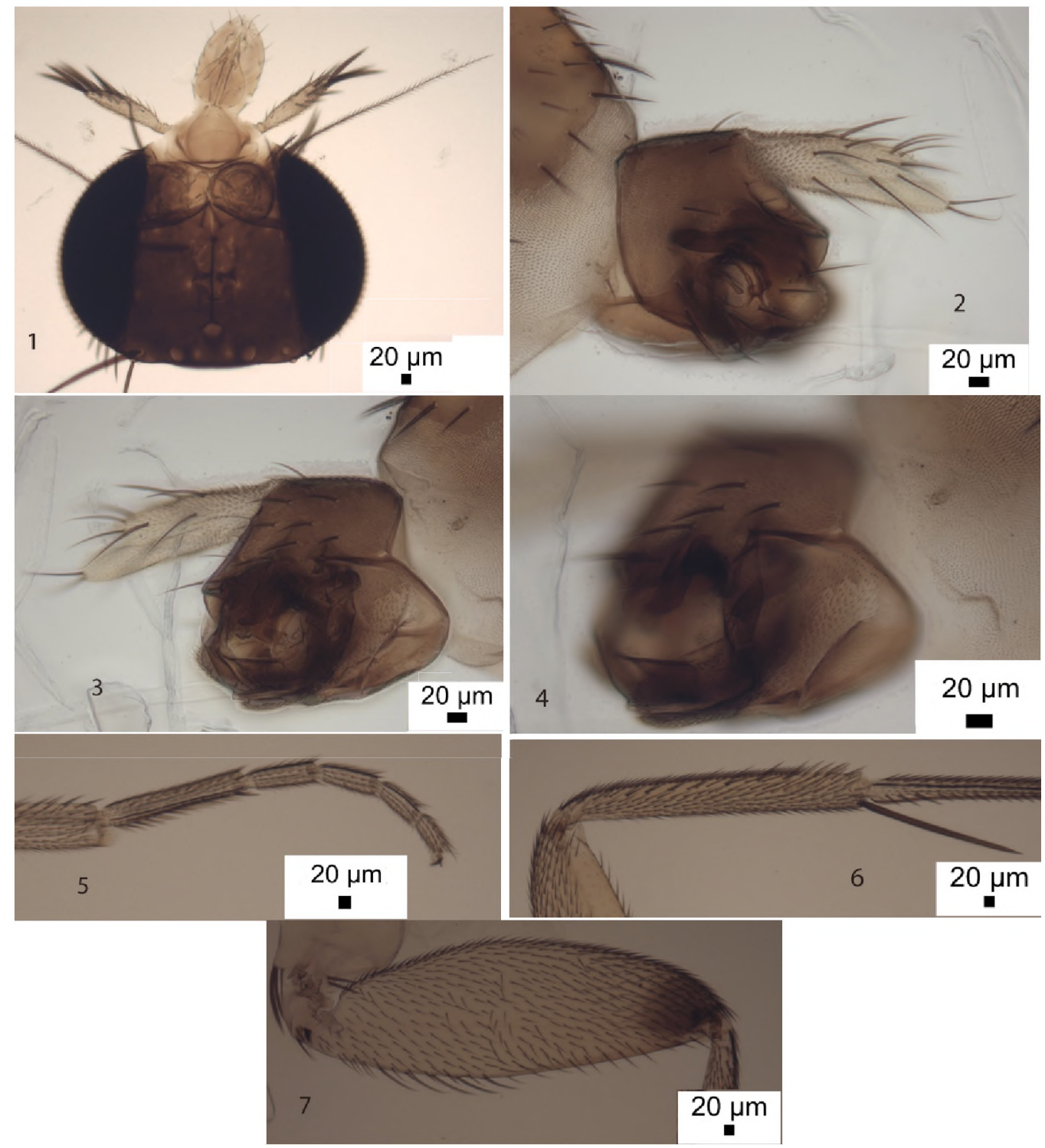

Figs 1-7. Megaselia garwolinensis $\mathbf{n}$. sp., male: 1 - frontal view of head, 2 - left face of hypopygium, 3 - right face of hypopygium, 4 - right face of hypandrium, 5 - front tarsus, 6 - mid tibia; 7 - hind femur. 


\section{ACKNOWLEDGEMENTS}

We thank Piotr Goliszewski (Forest District Garwolin) for his valuable help during our study. RHLD's studies of Phoridae are currently supported by grants from the Balfour-Browne Trust Fund (University of Cambridge). Ewa Durska is benefited from SYNTHESYS support made available by the European Community - Research Infrastructure Action under the FP6 Structuring the European Area Programme AT-TAF 543 and SE-TAF 1833. ED's research on Phoridae is supported by a grant from the National Science Centre (NCN nr 2011/01/B/NZ8/03005).

\section{REFERENCES}

BUCK M. \& DISNEY R. H. L. 2001. Revision of the Megaselia giraudii and $M$. densior species complexes of Europe, including ecological notes (Diptera, Phoridae). Beiträge zur Entomologie 51:73-154.

DISNEY R. H. L. 1983. A useful new character in the giant genus Megaselia (Diptera: Phoridae) with two new species from Britain. Zeitschrift für angewandte Zoologie 70: 225-234.

Disney R. H. L. 1989. Scuttle Flies - Diptera Phoridae Genus Megaselia. Handbooks for the Identification of British Insects $10(8): 1-155$.

DiSNEY R. H. L.1994. Scuttle flies: The Phoridae. Chapman and Hall, London, 467 pp.

DisNey R. H. L.2001a. Family Phoridae. In: Soós A. and Papp L. (eds) Catalogue of Palaearctic Diptera. Volume 7 (Dolichopodidae - Platypezidae), Akademia Kiado, Budapest, pp 143-204.

DiSNEY R. H. L. 2001b. The preservation of small Diptera. Entomologist's Monthly Magazine 137: 155-159.

DisNEY R. H. L. \& DURSKA E. 1998. A new genus and species of Phoridae (Diptera) from Poland. European Journal of Entomology 95: 437-453.

DISNEY R. H. L. \& DURSKA E. 2011. Five new species and three new records of Megaselia Rondani (Diptera: Phoridae) from Pisz Forest (Poland). Annales Zoologici 61(3): 527-534.

MARSHALL S. A. 2012. Flies: the natural history and diversity of Diptera. New York, Firefly Books, 615 pp.

OLDROYD H. 1964. The Natural History of Flies. Weidenfeld and Nicolson, London, 324 pp.

\section{STRESZCZENIE}

\section{[Nowy gatunek z rodzaju Megaselia (Diptera: Phoridae) i dwa nowo wykazane dla fauny Polski]}

W pracy został opisany nowy dla nauki gatunek - Megaselia garwolinensis. Ponadto, poza wymienionym gatunkiem, w materiale Phoridae, zebranym metodą żóltych misek, ustawionych na pożarzysku w Lasach Garwolińskich $\mathrm{k}$. Warszawy, stwierdzono po raz pierwszy w Polsce dwa inne gatunki z rodzaju Megaselia: $M$. bifida i $M$. citronella. 